\title{
Rafał Kowalczyk
}

Uniwersytet Wrocławski

e-mail: Rafal.kowalczyk@uwr.edu.pl

\section{USTROJOWA REGULACJA DANINOWYCH DOCHODÓW WLASNYCH GMIN}

\section{FUNDAMENTAL REGULATION \\ OF THE TAX OWN INCOME OF COMMUNES}

DOI: $10.15611 / \mathrm{pn} .2017 .485 .20$

JEL Classification: K30, K34

Streszczenie: Decentralizacja administracji publicznej, będąca efektem przemian ustrojowych, wymusiła dokonanie zmian w zakresie podziału dochodów publicznoprawnych. Państwo wyposażyć musiało jednostki samorządu terytorialnego w system dochodów, który pozwoliłby im realizować wszystkie przynależne zadania publiczne, tylko bowiem wtedy można mówić o samodzielnym podmiocie publicznym. Wobec tego jednak, że podział dochodów publicznych dokonywany jest w warunkach ograniczonej ich dostępności, zasadnicze znaczenie zyskuje ustalenie granicy pomiędzy tymi, które stanowią dochód państwa, a tymi, które są dochodem jednostki samorządu terytorialnego. $Z$ tego też powodu na szczególną uwagę i rozważania zasługują gwarancje prawne wyposażenia tych jednostek w dochody publicznoprawne. Przedmiotem przedmiotowych rozważań jest więc przede wszystkim ustalenie, czy ustrojowe reguły podziału tych dochodów znalazły swoje zastosowanie w przepisach prawa krajowego, a na ile gwarancje te nie są przestrzegane.

Słowa kluczowe: konstytucja, władztwo dochodowe, dochody, podatki, opłaty.

Summary: The decentralization of public administration, also involving the decentralization of public finances, has forced the creation of legal solutions for the distribution of public income. The state had to equip local self-government units with a revenue system that would enable them to carry out all publicly related tasks. The distribution of public revenues is made under conditions of limited availability, it is crucial to establish a boundary between those that constitute state revenue and those which are the income of a local government unit. The subject matter of the discussion is above all to determine whether the systemic rules of division of these incomes have been applied in the law.

Keywords: constitution, income authority income, taxes, fees. 


\section{Wstęp}

Decentralizacja administracji publicznej, znajdująca swój wymiar również w decentralizacji finansów publicznych, wymusiła stworzenie rozwiązań prawnych w zakresie podziału dochodów publicznoprawnych. By zapewnić realny byt i funkcjonowanie jednostek samorządu terytorialnego jako podmiotów publicznoprawnych, państwo wyposażyć musiało te jednostki między innymi w system dochodów, który pozwoliłby im realizować wszystkie powierzone zadania publiczne. Stworzony ustrój finansowy samorządu oparto na dwóch podstawowych rodzajach dochodów powszechnie w doktrynie systematyzowanych jako dochody własne i transferowe. Charakter prawny, uzasadnienie prawne i ekonomiczne tego podziału uprawniają, by uznać dochody własne za bezpośrednią realizację zasady decentralizacji finansów publicznych, pozwalających tym jednostkom na prowadzenie samodzielnej gospodarki finansowej, natomiast druga grupa dochodów powinna być postrzegana jako instrument wprowadzenia mechanizmów wyrównawczych i wspomagających jednostki samorządu terytorialnego ekonomicznie słabsze, bądź też mechanizm rekompensujący realizację powierzonych zadań. Oba rodzaje dochodów służą zapewnieniu gwarancji samodzielności samorządu terytorialnego, jednakże inny jest sposób ich regulacji prawnej, a w szczególności możliwości wpływania na ich wysokość. O ile dochody transferowe ze swej istoty poddane zostały w większości woli państwa w zakresie wysokości i celu ich przeznaczenia, o tyle w przypadku dochodów własnych, ich źródła, zakres regulacji oraz delegacja do regulacji przez same jednostki samorządu terytorialnego powinny być postrzegane jako podstawowa gwarancja prawna samodzielności finansowoprawnej tych jednostek, a co za tym idzie, poddawane jedynie ograniczonej ingerencji państwa (ustawodawcy), tak by nie naruszyć granicy pomiędzy decentralizacją a dekoncentracją finansów publicznych. Polski model samorządu terytorialnego zakłada daleko idącą decentralizację finansów publicznych, w oparciu o szeroką gamę dochodów własnych poszczególnych jednostek ${ }^{1}$. Podniesiony w tytule problem badawczy dotyczy przede wszystkim sposobu oraz zakresu regulacji prawnej w przepisach ustrojowych (Konstytucja RP i EKSL) oraz ich doprecyzowania w przepisach szczególnych, ocenianych przez pryzmat spójności tych regulacji. Analiza powołanych powyżej przepisów ustrojowych pozwala formułować szereg zasad, które z różnym skutkiem zostały (bądź nie) wprowadzone do porządku prawnego. Wśród zasad odnoszących się bezpośrednio do systemu dochodów jednostek samorządu terytorialnego wskazać można zasadę dywersyfikacji dochodów, zasadę terytorialności dochodów i zasadę wyposażenia tych jednostek w instrumenty władztwa dochodowego. Metodami badawczymi wykorzystanymi w opracowaniu są przede wszystkim metoda dogmatyczna, lecz autor dla zobrazowania reguł ustrojowych przywołanych w opracowaniu korzysta również z metody empirycznej.

${ }^{1} \mathrm{~W}$ Europie istnieje wiele systemów regulacji finansów samorządowych od scentralizowanych, poprzez mieszane, aż do zdecentralizowanych, zob. [Guziejewska 2006, s. 13]. 


\section{Klasyfikacja dochodów jednostek samorządu terytorialnego}

Podział dochodów publicznych dokonywany jest w warunkach ograniczonej ich dostępności, stąd kardynalne znaczenie zyskuje ustalenie granicy pomiędzy tymi, które stanowią dochód państwa, a tymi, które są dochodem jednostki samorządu terytorialnego. Jeszcze istotniejsze ze względów wskazanych we wstępie wydaje się ustalenie granicy wpływów państwa na dochody tych jednostek. W doktrynie prawa finansowego utrwalone zostały dwie metody ustalenia wzajemnych relacji (podziału) pomiędzy samorządem terytorialnym i państwem, w zakresie podziału publicznych zasobów finansowych [Niezgoda 2012]. Podział ten musi być dokonywany przy uwzględnieniu i respektowaniu zasady proporcjonalności i adekwatności. Pierwsza z tych reguł zakłada wyposażenie jednostek samorządu terytorialnego $\mathrm{w}$ środki umożliwiające tym jednostkom realizację ich zadań. $\mathrm{Z}$ kolei zasada adekwatności zakłada adekwatne do powierzonych zadań wyposażenie jednostek samorządu terytorialnego $\mathrm{w}$ środki publiczne. W praktyce założenia te realizowane są w różnym stopniu ${ }^{2}$. Przyjęte zasady podziału dochodów publicznych wynikają z aktów normatywnych, do których należy zaliczyć przepisy ustrojowe - przede wszystkim Konstytucję RP [Ustawa z 2 kwietnia 1997], Europejską Kartę Samorządu Lokalnego [Umowa z 15 października 1985], ustawy samorządowe [Ustawa z 8 marca 1990], jak również regulujące gospodarkę finansową - ustawę o finansach publicznych [Ustawa z 27 sierpnia 2009] i ustawę o dochodach jednostek samorządu terytorialnego [Ustawa z 13 listopada 2003]. Jednocześnie należy wskazać na szereg zasad sformułowanych przez doktrynę prawa, a dotyczących zasad podziału i struktury dochodów własnych jednostek samorządu terytorialnego, które częściowo znalazły swój odpowiednik w normach prawnych, a niektóre $\mathrm{z}$ nich są realizowane w sposób niepełny lub zmodyfikowany [Kornberger-Sokołowska 2012, s. 26].

Punktem wyjścia powinny być przepisy rangi generalnej regulujące ustrój państwa oraz samorządu terytorialnego, do których zaliczyć należy zarówno Konstytucję RP, jak i Europejską Kartę Samorządu Terytorialnego, której Polska jest stroną i której postanowienia zobowiązała się wprowadzić do swojego porządku prawnego. Zarówno przepisy Konstytucji RP, jak i EKSL [Lipowicz 1991, s. 75 i n.] gwarantują jednostkom samorządu terytorialnego udział w dochodach publicznych (art. 167 ust. 1 Konstytucji RP), wskazując rodzaje tych dochodów i dokonując częściowej klasyfikacji (jak w art. 167 ust. 2 Konstytucji RP) na dochody własne, subwencje i dotacje. Regulacje te nie odbiegają zasadniczo od innych regulacji konstytucyjnych krajów europejskich, w których istnienie władztwa dochodowego (finansowego) wskazuje się jako realną i zasadniczą cechę samorządu terytorialnego [Stasikowski 2005, s. 169; Helnarska 2008, s. 194].

\footnotetext{
${ }^{2}$ Krytyczną ocenę realizacji zasady adekwatności formułuje między innymi Wyszkowska [2014, s. 13 i n.].
} 
W dalszych przepisach dotyczących struktury dochodów jednostek samorządu terytorialnego oba akty prawne różnią się od siebie. W art. 168 Konstytucji RP ustrojodawca gwarantuje jednostkom samorządu terytorialnego prawo ustalania wysokości podatków i opłat na zasadach wynikających z ustaw kreujących te dochody. Tymczasem w Europejskiej Karcie Samorządu Lokalnego wskazuje się na konieczność zapewnienia jednostkom samorządu terytorialnego w ustawodawstwie krajowym dochodów z podatków i opłat lokalnych, wraz z możliwością ustalania ich wysokości na warunkach wynikających z ustawy (art. 9 ust. 3 EKSL). Gramatyczna różnica $\mathrm{w}$ obu powołanych przepisach sprowadza się przede wszystkim do tego, że Konstytucja RP (a za nią również inne ustawy) nie zapewnia wszystkim jednostkom samorządu terytorialnego udziału w podatkach i opłatach lokalnych, ograniczając się jedynie do zapewnienia im możliwości kształtowania ich wysokości. Tymczasem EKSL, inaczej niż Konstytucja RP, wskazuje na konieczność zagwarantowania wszystkim jednostkom samorządu terytorialnego udziału w podatkach i opłatach lokalnych. Bazując więc na wykładni językowej, należy wskazać na brak korelacji pomiędzy znaczeniem powołanych przepisów. Taki stan rzeczy nie jest niczym odosobnionym w europejskim porządku prawnym, bowiem konstytucje innych państw również różnią się od brzmienia przepisów Karty i w zróżnicowanym zakresie regulują sposób wyposażenia jednostek samorządu terytorialnego w dochody własne. W niektórych państwach - tak jak w Konstytucji Republiki Francuskiej w art. 72-2 - wskazuje się na zasadę, iż wspólnoty terytorialne korzystają ze źródeł dochodów, którymi mogą swobodnie dysponować na zasadach określonych w ustawie. Mogą one otrzymywać całość lub część podatków wszystkich rodzajów. Ustawa może upoważnić je do ustalania wymiaru i stawek podatku w określonych granicach. Dochody fiskalne i inne źródła własne wspólnot terytorialnych stanowią, dla każdej kategorii wspólnot, podstawową część całości ich źródeł dochodów. W Ustawie Zasadniczej RFN brak jest szczegółowych regulacji poświęconych finansom jednostek samorządu terytorialnego ze względu na federalistyczny charakter tego państwa i przeniesienie szczegółowych regulacji do prawa krajowego (landów), a co za tym idzie -różne zasady kształtowania przedmiotowego zakresu. W ustawie zasadniczej Republiki Słowacji znajdują się bardzo ogólne postanowienia regulowane przede wszystkim w art. 65 , jednakże na uwagę zasługuje zapis mówiący o tym, że ustawa określi, które podatki i opłaty stanowią dochody gminy, a które podatki i opłaty stanowią dochody wyższych terytorialnych jednostek. $Z$ kolei w ustawie zasadniczej Republiki Czech w art. 101 zawarto bardzo ogólne regulacje, wskazując, iż jednostki samorządu terytorialnego są korporacjami publicznoprawnymi, które mogą posiadać własny majątek i prowadzą gospodarkę na podstawie własnego budżetu. Jak więc widać z krótkiego porównania, Konstytucja RP nie odbiega znacząco od regulacji ustrojowych innych krajów, które bądź kazuistycznie wskazują na rodzaje dochodów przysługujących poszczególnym jednostkom samorządu, bądź wcale nie regulują tych kwestii. Polska ustawa organiczna wskazuje, podobnie jak Karta, że struktura dochodów publicznoprawnych jednostek samorządu terytorialnego powin- 
na być oparta na zasadzie ich zdywersyfikowania, przy jednoczesnym wyposażeniu tych jednostek w instrumenty kształtowania ich wysokości, powszechnie nazywane władztwem dochodowym. Dywersyfikacja dochodów powinna być rozumiana jako zróżnicowanie źródeł dochodów jednostek samorządu terytorialnego na tyle duże, by zapewnić elastyczną politykę dochodową, zapewniającą bezpieczeństwo finansowe jednostek samorządu. Uzależnienie gospodarki finansowej zarówno w gospodarce podmiotów publicznych, jak i prywatnych stwarza niebezpieczeństwo zaprzestania realizacji zadań, w sytuacji braku wydolności ze źródła dochodów. Analiza przepisów, przede wszystkim ustawy o dochodach jednostek samorządu terytorialnego, prowadzi do wniosku, iż ustawodawca krajowy zapewnił dywersyfikację dochodów na wszystkich szczeblach samorządu terytorialnego, tworząc wśród dochodów własnych podgrupy obejmujące dochody z tytułu danin publicznych, dochody z mająt$\mathrm{ku}$ tych jednostek oraz dochody pochodzące $\mathrm{z}$ wpłat jednostek organizacyjnych, a także inne, mniej istotne fiskalnie. Analizując jednak najważniejszą z tych grup, jaką niewątpliwie jest grupa danin publicznych, dochodzi się do wniosku o różnym wyposażeniu jednostek w poszczególne rodzaje tych danin.

\section{Postulaty ustrojowe wobec daninowych dochodów własnych}

Przepisy Konstytucji RP, jak i EKSL wskazują na co najmniej dwa rodzaje daninowych dochodów własnych, tzn. podatki i opłaty, które powinny być dochodami budżetowymi jednostek samorządu terytorialnego. Jednak jak stwierdzono wcześniej, sposób wyposażenia tych jednostek użyty przez oba akty prawne różni się w swym zakresie przedmiotowym. Rozwiązania ustawowe nie wyposażyły wszystkich jednostek samorządu w ten sam sposób nie tylko w zakresie podatków, ale i opłat publicznych, co wydaje się jednoznacznie naruszać ustrojową zasadę dywersyfikacji dochodów [Bury 2000, s. 21]. Stan prawny wynikający z ustaw regulujących strukturę dochodów jednostek samorządu terytorialnego ${ }^{3}$ zapewnia pełen katalog tych dochodów w przypadku gmin, przez wyposażenie powiatów jedynie w udziały w dochodach państwowych i opłaty publicznoprawne, skończywszy na województwach, dysponujących tylko dochodami z tytułu udziałów w podatkach dochodowych. Można oczywiście przyjąć, iż dywersyfikacja nie sprowadza się jedynie do wyposażania jednostek samorządu terytorialnego w dochody z tytułu danin publicznych, jednakże pozostałe źródła dochodów własnych albo nie mają charakteru publicznoprawnego gwarantującego ich pozyskanie (np. dochody z mienia), albo też brak jest instrumentów rzeczywistego oddziaływania na ich wysokość (np. dochody z państwowych podatków dochodowych). Wobec tego należy przyjąć, iż jedynie dochody z podatków i opłat samorządowych są zdatne do kształtowania ich

\footnotetext{
${ }^{3}$ Chodzi przede wszystkim o ustawę o dochodach jednostek samorządu terytorialnego, lecz wobec tego, że nie zawiera ona pełnego wyliczenia poszczególnych źródeł dochodów JST, należy też uwzględnić inne akty prawne, z których wynikają poszczególne tytuły dochodów.
} 
konstrukcji, a w konsekwencji wysokości dochodów, za sprawą realizacji wybranej polityki dochodowej jednostki samorządu. Taki też wniosek wysnuć można z analizy powołanych powyżej przepisów zarówno konstytucyjnych, jak i umowy międzynarodowej. Skoro bowiem w obu aktach wskazuje się na prawo (Konstytucja RP) lub powinność (EKSL) posiadania takich źródeł dochodów, to tym samym podkreśla się ich znaczenie w strukturze dochodów. Ponieważ jednak EKSL powszechnie traktowane jest jako zbiór przepisów o charakterze postulatywnym, ustawodawca krajowy ma dużą swobodę w stosowaniu standardów Karty w porządku krajowym [Ofiarski 2015, s. 386]. Jak widać w przytoczonych przepisach konstytucyjnych wybranych krajów europejskich, różne są zakresy wyposażenia samorządu terytorialnego w dochody własne. Polskie rozwiązania wydają się na tym tle i tak dość wiernie oddające intencje twórców Karty, by samorząd terytorialny posiadał dochody własne oparte na ich dywersyfikacji. Jedynym zastrzeżeniem jest brak pełnej gamy dochodów własnych w przypadku innych niż gminy jednostek samorządu, jednakże należy spojrzeć na przepisy konstytucyjne z perspektywy czasu, w którym były tworzone. Wieloszczeblowy samorząd stworzono w Polsce dopiero w 1998 r., chcąc więc wyposażyć wszystkie jednostki samorządu terytorialnego w dochody z „,własnych" podatków, należałoby takie stworzyć, przekazać dotychczas państwowe lub gminne - każda z tych decyzji byłaby niepopularna i mogła naruszyć stabilność finansową państwa lub gmin.

Kolejną ważną zasadą ustrojową dotyczącą dochodów własnych JST, które można wywieść z przepisów ustrojowych, jest terytorialność dochodów własnych. Postulat ten, powiązany z władztwem dochodowym (daninowym), zakłada wyposażanie jednostek samorządu terytorialnego w dochody o charakterze lokalnym, czyli związane z lokalną/regionalną jednostką samorządu terytorialnego. Idea tej zasady jest wielowątkowa i wykracza poza zakres prawny takiej regulacji. Powiązanie dochodów jednostki samorządu terytorialnego ze społeczeństwem, które dochodów tych dostarcza, powoduje poczucie sprawiedliwości społecznej i niewątpliwie mniejszy opór przed realizacją obowiązków publicznych. Alokacja środków dokonywana w skali lokalnej zapewnia powrót pobranych środków publicznych do tego samego społeczeństwa, za pośrednictwem realizacji lokalnych zadań publicznych, co z kolei stwarza mechanizmy kontroli redystrybucji środków publicznych. Lokalność dochodów realizowana jest zarówno przez podatki i opłaty o charakterze samorządowym, jak i (może przede wszystkim) przez zapewnienie jednostkom samorządu terytorialnego udziałów w podatkach dochodowych. W końcu zwrot przez państwo części dochodu z tytułu podatku dochodowego tym podmiotom, na terenie których dochód ten wytworzono, jest najlepszym środkiem budowania społeczeństwa obywatelskiego. Warto też na kanwie zjawiska malejącego znaczenia dla budżetu centralnego wpływów z podatków dochodowych formułować postulaty ciągłego zwiększania (wraz z trwającym powierzaniem nowych zadań publicznych jednostkom samorządu terytorialnego) udziału tych jednostek we wpływach z podatków dochodowych. Podobnie jak we wcześniejszej części, należy jednak zwrócić uwagę na fakt, że je- 
dynie w przypadku gminy ustawodawca realizuje w pełni postulat terytorialności dochodów własnych, rozumianych jako dochody, na których wysokość ma wpływ sama jednostka, poprzez oddziaływanie na elementy normatywne tych dochodów (terytorialność $\mathrm{W}$ sensie materialnym). W przypadku podatków dochodowych (a więc podstawowych dochodów podatkowych w powiatach i województwach) ich terytorialność ogranicza się jedynie do pochodzenia tych dochodów w ustalonej wysokości z terenu konkretnej jednostki samorządu terytorialnego (terytorialność w znaczeniu formalnym).

Istotnym postulatem ustrojowym dotyczącym źródeł dochodów jednostek samorządu terytorialnego jest wyposażenie tych jednostek w instrumenty władztwa dochodowego. Zapewnienie w systemie prawa instrumentów władztwa dochodowego rozpatrywać można przynajmniej w dwóch aspektach: jako uprawnienia i ograniczenia jednostek samorządu terytorialnego. Ograniczenie swobody kształtowania wysokości dochodów własnych sprowadza się przede wszystkim do ustawowej regulacji dochodów o charakterze publicznym, i to nie tylko poprzez wskazanie źródeł tych dochodów w ustawie (np. w ustawie o dochodach JST), a przede wszystkim poprzez uchwalenie ustaw materialnoprawnych, w których zawarte są wszystkie elementy konstrukcyjne danin publicznych. Powołane wcześniej przepisy EKSL i Konstytucji RP wskazują na ustawę (nie precyzując jaką) jako źródło szczegółowej i jedynej regulacji źródeł dochodów publicznoprawnych. Swoboda ustawodawcy kształtowania dochodów własnych jednostek samorządu terytorialnego nie oznacza jednak dowolności w tym zakresie, albowiem wynikająca z Konstytucji RP zasada samodzielności jednostek samorządu terytorialnego podczas wykonywania powierzonych im zadań wiąże również ustawodawcę. Z uwagi na to, że ramy działalności jednostek samorządu terytorialnego są tworzone w formie ustaw, również ograniczenia w zakresie przysługującej im samodzielności, w tym samodzielności finansowej, muszą spełniać wymagania formalnoprawne, a zatem być ustanowione $\mathrm{w}$ drodze ustaw [Wyrok TK z 26 września 2013]. Tak więc opisana wcześniej możliwość wpływania na wysokość dochodów publicznoprawnych sprowadza się jedynie do tych dochodów i w takim zakresie, jaki wynika z ustaw kreujących te dochody. Żadnych innych dochodów własnych o charakterze publicznym, poza tymi ustanowionymi ustawowo, jednostki samorządu terytorialnego nie mogą kreować [Miemiec 2005, s. 91]. W tym miejscu w ramach dygresji należy zwrócić uwagę na niedoskonałość rozwiązań krajowych regulujących źródła dochodów jednostek samorządu terytorialnego. Ustawa o dochodach JST, która w zamyśle miała być aktem kompleksowo regulującym i strukturę dochodów, i przynależność poszczególnych dochodów do budżetów konkretnych jednostek samorządu terytorialnego, realizuje to zadanie jedynie połowicznie. Ustawa o dochodach JST w przypadku niektórych dochodów, zwłaszcza podatkowych, jest jedyną podstawą prawną wprost stanowiącą o przynależności tego dochodu publicznego do budżetu gminnego. W ustawie o podatku rolnym [Ustawa z 15 listopada 1984], o podatku leśnym [Ustawa z 30 października 2002], o podatkach i opłatach lokalnych [Ustawa z 12 stycznia 1991], o podatku 
od spadków i darowizn [Ustawa z 28 lipca 1983], o podatku od czynności cywilnoprawnych [Ustawa z 9 września 2000] brak jest przepisów wprost decydujących o beneficjencie tych dochodów. W pozostałych imiennie wymienionych dochodach własnych o przynależności do dochodów gminnych decydują przepisy regulujące te dochody - art. 2 ust. 4 ustawy o zryczałtowanym podatku dochodowym od niektórych przychodów osiąganych przez osoby fizyczne (karta podatkowa) [Ustawa z 20 listopada 1998], art. 141 ust. 1 ustawy Prawo geologiczne i górnicze (opłata eksploatacyjna) [Ustawa z 9 czerwca 2011]. Ustawa zawiera też odesłanie do przepisów szczególnych, z których wynika przynależność wskazanego dochodu publicznego do budżetu gminy (w odniesieniu do innych jednostek samorządu terytorialnego ustawa nie wymienia żadnych imiennych dochodów).

Drugim wymiarem władztwa dochodowego jest prawo jednostki samorządu terytorialnego do kształtowania wysokości dochodów publicznoprawnych. Wskazana w przepisach Konstytucji RP oraz EKSL gwarancja wpływania na wysokość dochodów przez same jednostki będące beneficjentami tych dochodów powszechnie uznawana jest za jedną z podstawowych gwarancji samodzielności [Glumińska-Pawlic 2003, s. 47]. Co oczywiste, nie będzie miała zastosowania albo będzie bardzo ograniczona, w sytuacji gdy jednostka samorządu terytorialnego nie dysponuje dochodami z tytułu danin publicznych albo nie są one dochodami samoistnymi, tak jak w przypadku udziałów w podatkach dochodowych. Swoboda decydowania o elementach konstrukcyjnych tych podatków jest w przypadku samorządowych organów podatkowych praktycznie żadna. Zgodnie z art. 168 Konstytucji RP jednostki samorządu terytorialnego mają prawo ustalania wysokości podatków i opłat lokalnych w zakresie ustalonym w ustawie. Odpowiednikiem tego przepisu jest art. 9 ust. 3 EKSL stanowiący o tym, że przynajmniej część zasobów finansowych społeczności lokalnych powinna pochodzić z opłat i podatków lokalnych, których wysokość społeczności te mają prawo ustalać, w zakresie określonym ustawą. Przepisy te gwarantują jednostkom samorządu terytorialnego prawo do korzystania z instrumentów prawnych, umożliwiających tym jednostkom realny wpływ na konstrukcję dochodów zaliczanych do grupy daninowych, a ustawodawcę zobowiązują do stworzenia takich warunków. Instrumenty te muszą mieć swoją podstawę w ustawie (patrz wyżej), z której wynika zakres przedmiotowy i podmiotowy władztwa dochodowego. Zakres przedmiotowy tego władztwa wskazuje na te elementy konstrukcji normatywnej, które mogą być kształtowane przez jednostkę samorządu terytorialnego (np. stawki podatkowe, ulgi i zwolnienia), natomiast zakres podmiotowy wskazuje na organ uprawniony do korzystania z tych instrumentów (np. rada gminy, wójt). Na zakres przedmiotowy władztwa dochodowego (w ściślejszym ujęciu - władztwa podatkowego) należy spojrzeć w kilku płaszczyznach. Na pierwszy plan wysuwa się zagadnienie obligatoryjności i fakultatywności grupy dochodów publicznoprawnych (daninowych). Kształt ustawodawstwa krajowego (przepisy Konstytucji RP, ale również ustawy materialnoprawne) pozwala formułować tezę o obligatoryjności dochodów podatkowych i fakultatywności, choć w niepełnym zakresie, dochodów 
z tytułu opłat publicznych. Ten aspekt władztwa dochodowego, o którym mowa w przepisach ustrojowych (Konstytucja RP i EKSL), ma więc aspekt podstawowy, pozwala bowiem (bądź nie pozwala) decydować o wymiarze i poborze dochodów z określonego źródła publicznoprawnego. Wspomniana fakultatywność dochodów charakterystyczna jest dla niektórych opłat publicznych, które mogą zostać wprowadzone przez organ stanowiący jednostki, a wtedy stają się świadczeniem obligatoryjnym dla osoby zobowiązanej. Przykładami tych opłat są opłaty lokalne, opłaty pobierane za odprowadzanie wód opadowych do kanalizacji ogólnospławnej czy też opłaty adiacenckie. Co ciekawe, w przypadku niektórych opłat, zdecydowanie jednorodnych rodzajowo, występują różne rozwiązania w zakresie ich obligatoryjności, np. zarówno doktryna, jak i orzecznictwo sądowe przyznają charakter fakultatywny opłatom adiacenckim i charakter obligatoryjny opłatom planistycznym [Lorek 2010, s. 23; Bończak-Kucharczyk 2017; Prądnicki 2014; Wyrok Wojewódzkiego Sądu Administracyjnego w Krakowie, 2013].

Kolejną płaszczyzną przedmiotową władztwa dochodowego jest możliwość kształtowania elementów konstrukcyjnych poszczególnych dochodów publicznoprawnych. Choć struktura dochodów samorządu terytorialnego niewątpliwie faworyzuje gminy, to również w ich przypadku należy wskazać na różne możliwości wpływania na wysokość dochodów podatkowych - od jego braku w przypadku podatków dochodowych, przez bardzo ograniczony w przypadku podatków stanowiących dochód gmin, lecz wymierzanych i pobieranych przez państwowe organy podatkowe, aż po najpełniejszy zakres oddziaływania na konstrukcję podatków, tak jak w przypadku podatków obciążających nieruchomości. Ale i w przypadku tych podatków podstawowym ograniczeniem władztwa dochodowego jest ustawowa obligatoryjność tych dochodów, czyli brak możliwości rezygnacji z tych dochodów oraz ograniczenie stanowienia ulg i zwolnień jedynie do tych o charakterze przedmiotowym. Uprawnienia te realizowane są zarówno w sferze prawa materialnego (jako możliwość kształtowania elementów konstrukcyjnych, przede wszystkim stawek i ulg), jak i proceduralnego (przede wszystkim w zakresie stosowania ulg wobec podmiotów zobowiązanych w trakcie trwającego postępowania).

Zakres podmiotowy władztwa dochodowego należy rozumieć jako kompetencje organów jednostek samorządu terytorialnego do wpływania na wysokość dochodów publicznoprawnych. Kompetencje te przysługują organowi stanowiącemu, przede wszystkim w zakresie prawa materialnego, a więc w odniesieniu do kształtowania poszczególnych elementów konstrukcyjnych danin publicznych, w granicach przyznanych ustawowo kompetencji, ale również organ wykonawczy został wyposażony $\mathrm{w}$ takie instrumenty, choć przede wszystkim w sferze prawa proceduralnego, występując w roli organu podatkowego. Nie wszędzie jednak, jeśli chodzi o dochody lokalne, kompetencje te występują, i to zarówno w ujęciu przedmiotowym, jak i podmiotowym. W stosunku do niektórych podatków nazwa „lokalne” jest jedynie oznaczeniem ich beneficjenta, gdyż analizując konstrukcję podatku od czynności cywilnoprawnych i podatku od spadków i darowizn, należy stanowczo stwierdzić 
brak elementów władztwa dochodowego po stronie gminy. To organom państwowym przysługuje realne władztwo podatkowe, gdyż tylko te organy mogą stosować wobec podatnika ulgi oparte na przepisach ordynacji podatkowej, konsultując jedynie te uprawnienia z samorządowymi organami podatkowymi.

\section{Konkluzje}

Z przedstawionych rozważań wyłania się obraz niejednoznacznego realizowania przez ustawodawcę krajowego postulatów ustrojowych w zakresie gospodarki finansowej jednostek samorządu terytorialnego. Zarówno przepisy Europejskiej Karty Samorządu Lokalnego, jak i Konstytucja RP stanowią wzorce pewnych rozwiązań prawnych, które jednakże nie zawsze realizowane są w ustawodawstwie zwykłym; znamienne jest to, że same opisane powyżej akty ustrojowe bywają ze sobą rozbieżne zarówno w ujęciu legislacyjnym, jak i praktyki stosowania prawa. Wciąż pozostają nierozstrzygnięte zasadnicze wątpliwości dotyczące równego traktowania jednostek samorządu terytorialnego, w ujęciu struktury ich dochodów własnych. Szczególny sposób traktowania gmin oraz brak po stronie samorządu powiatowego i wojewódzkiego dochodów podatkowych (takich, co do których istnieją instrumenty kształtowania) stawia pod znakiem zapytania ich bezpieczeństwo finansowe, a przede wszystkim samodzielność, gdyż uzależnienie tych jednostek w dużej mierze (powiat), albo w znacznym stopniu (województwo), od transferów z budżetu państwa może okazać się niewystarczającym instrumentem ochrony ich samodzielności. Jednakże brak pełnego katalogu dochodów publicznoprawnych w odniesieniu do powiatów i województw, na gruncie Konstytucji czy EKSL, nie może być postrzegany jako naruszenie zasad ustrojowych, gdyż jednostki te posiadają zdywersyfikowane dochody własne, co prawda nie w takim samym zakresie jak gminy, lecz wypełniające podstawowe standardy stawiane regulacji prawnej w zakresie dochodów własnych. Wszystkie z wymienionych i omówionych powyżej zasad wyinterpretowanych z przepisów ustrojowych mają zastosowanie, choć w różnym zakresie, do poszczególnych szczebli samorządu. Jedyną wątpliwością, a jednocześnie postulatem powinno być jak najszybsze wyposażenie gmin we wszystkie elementy władztwa dochodowego w zakresie podatków w całości stanowiących ich dochód. Brak jest jakichkolwiek merytorycznych przesłanek, by dochody (podatek od czynności cywilnoprawnych, podatek od spadków i darowizn) lokalne realizowane były przez państwowe organy podatkowe.

\section{Literatura}

Bończak-Kucharczyk E., Ustawa o gospodarce nieruchomościami - Komentarz, System Informacji Prawnej LEX (28.07.2017).

Bury A., 2000, Dochody powiatów i województw w świetle postanowień Europejskiej Karty Samorzadu Terytorialnego, Samorząd Terytorialny, nr 3. 
Glumińska-Pawlic J., 2003, Samodzielność finansowa jednostek samorzadu terytorialnego w Polsce, Katowice.

Guziejewska B., 2006, Koncepcje samorządu terytorialnego a źródła jego finansowania, Samorząd Terytorialny, $\mathrm{nr} 5$.

Helnarska K.J., 2008, Samorzad terytorialny we Francji, [w:] Samorzad terytorialny w Polsce i Europie, red. J. Marszałek-Kawa, Wydawnictwo Adam Marszałek, Torun.

Konstytucja Republiki Czeskiej z dnia 16 grudnia 1992 r.

Konstytucja Republiki Francuskiej z 4 października 1985 r.

Konstytucja Republiki Słowackiej z dnia 23 lutego 2001 r.

Kornberger-Sokołowska E., 2012, Finanse jednostek samorzadu terytorialnego, Lexis Nexis, Warszawa.

Lipowicz I., 1991, Europejski standard samorządu terytorialnego a ustawodawstwo polskie, Samorząd Terytorialny, nr 11-12.

Lorek A., 2010, Oplata adiacencka i renta planistyczna, PRESSCOM, Wrocław.

Miemiec W., 2005, Prawne gwarancje samodzielności finansowej gminy w zakresie dochodów publicznoprawnych, Wrocław.

Niezgoda A., 2012, Podziat zasobów publicznych pomiędzy administrację rządowa i samorządowa, LEX a Wolters Kluwer business, Warszawa.

Ofiarski Z., 2015, Standard z art. 9 ust. 3 EKSL jako wzorzec kontroli na przyktadzie wybranych orzeczeń Trybunału Konstytucyjnego, [w:] EKSL a prawo samorzadu terytorialnego, red. M. Ofiarska, Uniwersytet Szczeciński, Szczecin.

Prądnicki K., 2014, Przesłanki ustalenia opłaty planistycznej, Lexis.pl (28.07.2017).

Stasikowski R., 2005, Gwarancje samorząności gminnej w systemie prawnym RFN $i$ RP, Branta, Bydgoszcz-Katowice.

Ustawa z dnia 2 kwietnia 1997 r. Konstytucja RP, Dz.U. 1997, nr 78, poz. 483 ze zm.

Ustawa z dnia 8 marca 1990 r. o samorządzie gminnym, t.j. Dz.U. 2016, poz. 446 ze zm.

Ustawa z dnia 9 czerwca 2011 r. Prawo geologiczne i górnicze, t.j. Dz.U. 2016, nr 1131 ze zm.

Ustawa z dnia 9 września 2000 r. o podatku od czynności cywilnoprawnych, t.j. Dz.U. 2016, nr 223 ze zm.

Ustawa z dnia 12 stycznia 1991 r. o podatkach i opłatach lokalnych, t.j. Dz.U. 2016, nr 716 ze zm.

Ustawa z dnia 13 listopada 2003 r. o dochodach jednostek samorządu terytorialnego, t.j. Dz.U. 2016 r., poz. 198 ze zm.

Ustawa z dnia 15 listopada 1984 r. o podatku rolnym, t.j. Dz.U. 2016, nr 216, ze zm.

Umowa z dnia 15 października 1985 r. Europejska Karta Samorządu Lokalnego, Dz.U. 1994, nr 124, poz. $607 \mathrm{ze} \mathrm{zm}$.

Ustawa z dnia 20 listopada 1998 r. o zryczałtowanym podatku dochodowym od niektórych przychodów osiąganym przez osoby fizyczne, Dz.U. 1998, nr 144, poz. 930 ze zm.

Ustawa z 27 sierpnia 2009 r. o finansach publicznych, t.j. Dz.U. 2016, poz. 1870 ze zm.

Ustawa z dnia 28 lipca 1983 r. o podatku od spadków i darowizn, t.j. Dz.U. 2006, nr 205 ze zm.

Ustawa z dnia 30 października 2002 r. o podatku leśnym, t.j. Dz.U. 2016, nr 374 ze zm.

Ustawa Zasadnicza Republiki Federalnej Niemiec z dnia 23 maja 1949 r.

Wyrok TK z dnia 26 września 2013 r. K 22/12, SIP LEX.

Wyrok Wojewódzkiego Sądu Administracyjnego w Krakowie z dnia 18 grudnia 2013 r. II SA/Kr 1246/13, SIP LEX.

Wyszkowska D., 2014, Zastosowanie zasady adekwatności dochodów do zadań jednostek samorząu terytorialnego, Finanse Komunalne, nr 7-8. 